\title{
The Effect of Organizational Culture, Transformational Leadership, and Interpersonal Communication on Private High Schools Teachers' Job Satisfaction
}

\author{
Ekowati \\ Post Graduate Program \\ Universitas Pakuan Bogor, Indonesia \\ ekowati.spdmpd@yahoo.com

\section{Thamrin Abdullah} \\ Post Graduate Program \\ Universitas Pakuan, Bogor, Indonesia \\ thamrin.unpak@yahoo.com

\section{Widodo Sunaryo} \\ Post Graduate Program \\ Universitas Pakuan, Bogor, Indonesia \\ widodos.unpak@yahoo.com
}

\begin{abstract}
The aim of this study is to examine the influence of organizational culture, transformational leadership and interpersonal communication on teachers' job satisfaction either individually or jointly. Variables of Organizational Culture, Transformational Leadership and Interpersonal Communication serve as independent variables while the dependent variable is Teacher's Job Satisfaction. The study was conducted on randomly selected 200 teachers of Private High School in the city of Bekasi, West Java, Indonesia. Using mix method, sequential explanatory design is applied where quantitative come first. The study both quantitatively and qualitatively reveals that there is a positive significant relationship among variables under the following distribution of coefficient of correlation: Organizational Culture to Teacher's Job Satisfaction $=0.507$, Transformational Leadership to Teacher's Job Satisfaction $=0.241$, Interpersonal Communication to Teacher's Job Satisfaction $=0.474$ and when tested together it produces coefficient of correlation $=0.55$ indicating the existence of other $45 \mathrm{~b} \%$ variables not including in the model affecting factors affecting Working Satisfaction within the private high school teachers'working environment,
\end{abstract}

Keywords: Organizational Culture, Transformational Leadership, Interpersonal Communication, Job Satisfaction

\section{INTRODUCTION}

The quality of education is determined by several factors, including the facilities, resources and the environment. Each of these factors provide its own influence on the quality of education, but many experts say that teachers have a major influence on the quality of education. The ability of teachers in providing services to students, teaching methods and means of learning given a major need in the implementation of education. One part of the importance of a quality education is to achieve job satisfaction of teachers.

Job satisfaction is determined by external factors and factors from within. External factors include the policy, the environment, wage system and the state of society in the work environment. In this study, the researchers focused organizational culture, internal communications and transformational leadership. These three factors are interesting to be examined to obtain information on job satisfaction of teachers working in private high school in Bekasias the buffer area of Jakarta, the country's capital. The need to create working atmosphere and private teacher job satisfaction in Bekasi is unique as the city is strongly influenced by metropolitan environment. Researchers made the three predictor variables of organizational cultures, transformational leadership and interpersonal communication as a stepping stone to predict the state of job satisfaction as there is no sufficient information how job satisfaction will provide benefits for education, especially in Bekasi.

Based on the background and the results of the identification of the problem, the formulation of the problem is: 
Does organisational culture positively affect private school teacher's job satisfaction?

Does transformational leadership positively affect private school teacher's job satisfaction?

Does interpersonal communication positively affect private school teacher's job satisfaction?

Do organisational culture, transformational leadership and interpersonal communication altogether positively affect private school teacher's job satisfaction?

\section{LITERATURE REVIEW}

Organizational Culture stated by Colquit, J. Jeffery A, Lepine and Michel J. Wessor (2009) that defines: "Organizational culture as the shared social knowledge within an organization regarding the rules, norms, and values that shape the attitudes and behaviors of its employees ".

Based on the theories mentioned above, it can be synthesized that in school organization, organizational culture is a pattern of basic assumptions or basic philosophy agreed upon and developed at the school to be implemented and achieved.

Bernard M. Bass and Ronald E. Riggio (2006) defines transformational leadership as behavior which can stimulate and inspire followers to achieve results in the process of developing leadership skills, vision and goals given organization, to challenge itself to innovate, solve problems, and develop the ability of the leadership to subordinates through guiding, mentoring, ,challenging and supporting. "Transformational leaders, on the other hand, are then those who stimulate and inspire followers both in achieving extraordinary outcomes and developing their own leadership capacity".

Gary Yukl (2006) stated that transformational leadership is the behavior of a leader who is able to call on his followers moral values in their efforts to raise awareness of ethical issues and mobilize energy and resources to reform institutions. Factors associated with the above definition are: 1) communicating the vision, 2) expressive, 3) a risk taker and sacrificed himself, 4) communicating high expectations, 5) consistent behavior vision, 6) managing the respect of subordinates against leadership, 7) establishing the existence of a group or organization, 8) empowering subordinates.

Based on the theories mentioned above, it can be synthesized that transformational leadership is the behavior of a leader who can inspire subordinates (teachers) to commit to the vision of the school, communicating, motivating, directing, empowering subordinates, to be a model, developing the potential of subordinates as well as a new perspective in solving the problem. The dimensions and indicators are : 1) the influence of the ideal toward subordinates, 2) the inspiration that motivates, 3) intellectual stimulation, 4) treatment of subordinates, 5) communication skills, 6) the giver of challenge and support.

Gibson, et.al (2012) argues interpersonal communication is the main way in daily managerial communication as usually more than a quarter of managerial communication occurs face to face with the following indicators: a) transparency, b) honesty, c) feedback. Schermerhorn (2004) stated that it would be useful to look at human communication as a process to send and receive symbols containing a message from one person to another. The basic process between people is the basis for the discussion of issues of greater communication within an organization and there are three factors in interpersonal communication to foster good interpersonal relationships: a) believe (trust), b) supportive attitude (supportiveness), c) an open attitude (open-mindedness).

McShane and Glinov (2012) concluded that effective interpersonal communication depends on the ability of the sender to get messages from others and receiver performance as an active listener. The indicators are: a) empathy, a person's ability to understand, sensitive to the feelings, thoughts, and situations of others, b) repeating the message: repeating key points several times, c) using time effectively: the message that compete with another message, d) noise, so that the recipient is not disturbed by anything else, and descriptive, focusing on the problem, not the person. Based on the above description, it can be synthesized that interpersonal communications are the delivery and reception of messages in the exchange of information between individuals, directly as well as generating feedback so that the message can be understood by the two parties. The indicators are a) the transmission of information, b) sensitive to the feelings of others, c) feedback, d) information acceptance e) using time effectively, f) comfortable conditions when obtaining information. 
Rue and Byars (2007) defines job satisfaction as an employee's general attitude towards work. This can be affected by factors such as working conditions, pay and benefits, employee attitudes towards the organisation, supervision of the work, the age and health. That mindset can be negative or positive depending on the mindset of the employees toward the main components of job satisfaction. Rue and Byars give us the understanding that job satisfaction does not come naturally for granted; but many factors that cause an employee be satisfied. Robins and Judge (2013) defines that job satisfaction is evaluative statement either for pleasure or unpleasure toward individual objects or events. Discontent is essentially a person's assessment of the work. Many factors affect employee satisfaction, including: salaries, allowances, achievement, autonomy, recognition, communication, working conditions, the importance of work, coworkers, professionalism, organisational climate, interpersonal relationships, working for a prominent institutions, supervisory support, positive activity, job security, workplace flexibility, working in a cohesive team and genetic factors. Low work satisfaction is associated with the laborious tasks such as documentation, repetition task, the tension in the role expectations, ambitious role, conflicted role, feeling overloaded, increasing the need to be available for overtime, a co-worker relationships, personal factors and organisational factors.

Based on theory explored, it can be concluded that job satisfaction is an attitude or feelings towards a job that makes him feel satisfied or not. Some indicators that are related to job satisfaction of school teachers are (a) the receipt of salary (b) promotion opportunities (c) organisational environment, (d) allowances.

\section{DATa Collection}

This study applies mix method with direct observation to the field aimed at analyzing the phenomenon occur when the research took place then confirm the finding by using direct depth interview. This way, writers apply Sequential Explanatory Mixed Methods. Descriptive statistics and quantitative analysis are used for finding initial solution to the problem encountered. The sample of this study were 200 private high school teachers located in three schools under the category upper, medium and lower ranks in Bekasi, West Java Indonesia.

Techniques of data collection in this study is in the form of questionnaire. The normality assumption is prerequisites to proceed to further test. Analysis is conducted with multiple linear regression and hypothesis testing is performed at a significance level of 0.05 .

Depth interview with vice headmaster was perform to confirm the result of quantitative findings. The implication of the research findings is then discussed.

\section{RESULT AND DISCUSSION}

The teachers of listed organisations were asked to participate in the survey by responding their opinions for four different measures in Organizational Culture, Transformational Leadership, Interpersonal Communication and Job Satisfaction. The normality is performed with Lilliefors test. Data are normally distributed as the value of each variable is not exceeding the critical value for Lilliefors test. The Lilliefors normality test values for Organizational Culture, Transformational Leadership, Interpersonal Communication to Job Satisfaction are 0.483, 0.330 and 0.355 respectively below the critical value of 0.626 for $\mathrm{n}=200$.

\subsection{The Effect of Organizational Culture to Job Satisfaction}

Hypothesis testing confirms that organizational culture positively affects job satisfaction with correlation coefficient value of 0.507 and the coefficient of determination $=0.257$. This means that only $25.7 \%$ of job satisfaction is determined by organizational culture, while the other $74.3 \%$ is contributed by other variables. Similarly, result of qualitative research interviews, observation and documentation in three private Junior High School in the city of Bekasi, confirms the tendency of the relationship between organizational cultures with job satisfaction. This finding strengthens the quantitative research hypothesis results testing that there is a positive significant relationship between organizational culture and job satisfaction.

This finding is in line with Kotter and Heskett, (2009) that defines organizational culture as a collective social knowledge in organization related to rules, norms and values forming behavior of organization members. Another supporting theory is from Gibson, et.al, (2012) postulating that organizational culture is employees' point of view in creating mode of confidence, value and hope. 


\subsection{The Transformational Leadership to Job Satisfaction}

Hypothesis testing confirms that transformational leadership positively affects job satisfaction with the coefficient of determination $=0.058$ This means that only $5.8 \%$ of job satisfaction is determined by transformational leadership variable, while the other $94.2 \%$ is contributed by other variables. Similarly, result of qualitative research interviews, observation and documentation in three private Junior High School in the city of Bekasi , confirms the tendency of the relationship between transformational leadership with job satisfaction. This finding strengthens the quantitative research hypothesis results testing that there is a positive significant relationship between transformational leadership and job satisfaction.

\subsection{The Effect of Interpersonal Communication to Job Satisfaction}

Hypothesis testing confirms that interpersonal communication positively affects job satisfaction with the coefficient of correlation $=0.474$ and coefficient of determination $=0.225$. This means that $22.5 \%$ of job satisfaction is determined by interpersonal communication variable, while the other $77.5 \%$ is contributed by other variables. Similarly, result of qualitative research interviews, observation and documentation in three private Junior High Schools in the city of Bekasi confirms the tendency of the relationship between interpersonal communication with job satisfaction. This finding strengthens the quantitative research hypothesis results testing that there is a positive significant relationship between interpersonal communication and job satisfaction.

\subsection{Interaction of Organizational Culture, Transformational Leadership and Interpersonal Communication to Job Satisfaction}

When tested together, hypothesis testing results show that there is a significant relationship between organizational culture, transformational leadership and interpersonal communication to job satisfaction. The regression equation generated is $\hat{Y}=323,71+0,554 \mathrm{X}_{1}+0,7647 \mathrm{X}_{2}-0,353 \mathrm{X}_{3}$ with correlation of coefficient values $=0.742$ and the coefficient of determination $=0.550$. This means that $55 \%$ of job satisfaction is caused by variables of organizational culture, transformational leadership and interpersonal communication while $45 \%$ is contributed by other variables not included in the model. Result of qualitative research interviews, observation and documentation in three private Junior High School in the city of Bekasi also confirms the relationship among organizational culture, transformational leadership and interpersonal communication to job satisfaction. This finding strengthens the quantitative research hypothesis results testing that there is a positive significant relationship among those mentioned variables. Qualitative research also reveals that other factors affecting job satisfaction in the respective school are 1) less management transparent 2) keen competition among schools. 3) merit system which is not reactive to the environmental changes.

\section{CONClusion}

The findings reveal that there is a positive and significant direct effect between organizational culture, transformational leadership and interpersonal communication to job satisfaction.

Based on the initial design of the constellation between variables, the results showed that the contribution of organizational culture to job satisfaction is $25.75 \%$, transformational leadership is 5.80 $\%$, and interpersonal communication is $2.25 \%$ indicating the highest individual contribution to the teachers' job satisfaction is organizational culture. When combined together, contribution of the three variables of organizational culture, transformational leadership and interpersonal communication reaches $55 \%$ indicating the contribution of other variables not included in the model to predict job satisfaction are $45 \%$ confirming this model is of marginal good-fit. Other researchers wishing to conduct similar studies may include other variables such as; teacher professionalism, achievement motivation, work culture of teachers, teachers' resilience, creativity, work experience, training, principal's management, decision-making techniques and so forth. . Factors related to personal characteristics, organizational environment, and leadership behaviors found to predict job satisfaction mainly within private high schools' context which is rarely explored.

\section{REFERENCES}

Bernard M. Bass and Ronald E. Riggio. Transformational Leadership, New Jersey: Lawrence Erlbaum Associates, Inc., 2006. pp.35.

Colquitt, Jason A. Jeffery A. Lepine and Michael J. Wesson. “Organizational Behavior Improving 
The Effect of Organizational Culture, Transformational Leadership, and Interpersonal Communication on Private High Schools Teachers' Job Satisfaction

Performance and Commitment in the Workplace." New York: McGraw - Hill. 2009. pp.131.

Gary Yukl, Leadership in Organizations ,(New York: Pearson Education International, 2006), pp.251 $\& 254$

Gibson, J.L., John M. Ivancevich, James H. Donelly Jr, \& Robert Konopaske. Organizational: Behavior, Structure, Processes, 2012, New York: Mc Graw-Hill. pp. 344-345.

Kotter, John P., and James L. Heskett, Corporate Culture and Performance. New York: The Free Press, 2009, pp.44-45.

McShane, S., \& Von Glinow, M. (2012). Organizational behavior. McGraw-Hill Higher Education. pp.56-57.

Robbins, S., Judge, T. A., Millett, B., \& Boyle, M. "Organisational behaviour." Pearson Higher Education AU, 2013, pp. 67.

Rue, Leslie W. and Lioyd L Byars. "Supervision Key Link to Productivity”. New York: Mc Graw Hill, 2007, pp.123. 